\title{
The Impact of Luminescence in Technological Scale
}

\author{
Jagannathan Thirumalai
}

Additional information is available at the end of the chapter

http://dx.doi.org/10.5772/64625

\section{A epigrammatic testimony of luminescence}

From the prehistoric times, the term 'luminescence' is more fascinating towards mankind. One can simply look at the logically occurring luminescence through the aurora borealis, luminescent wood, glow worms, putrid fish and meat [1]. The effect was wearing a veil in secrecy and illustrated consequently in the Middle Ages and past. The most primitive printed report of a solid-state luminescent material originated from a Chinese text that was published in the Song dynasty (960-1279 A.D.), quite referred to a book (never recovered) from the period 140-88 B.C. It narrates a painting picture of a cow munch grass in an outside field. In the darkness, the cow would be seen repose within a shelter [1-3]. Perhaps, the first man-made ink was exploited using a persistent phosphor material. Harvey [3] dispenses a tremendous description of these untimely interpretations far beyond the purview of the current reassess. In general, the name phosphorus is mentioned only for the chemical element, whereas specific microcrystalline luminescent materials are referred as phosphors. The first artificial phosphor exemplified in Western literature dates from 1603. Then, the Italian alchemist and shoemaker Vincenzio Cascariolo's phosphor (1870) manifest was the earliest commercially available phosphor, referred to as "Balmain's paint," a barium sulphide preparation. Phosphors (lightbearing materials) are optical transducers that yield luminescence when the material is suitably excited. The idiom 'luminescence' (the Greek translation of lucifer, means light bearer) was first initiated by the German physicist, Eilhardt Wiedemann, in 1888, to facilitate the discrimination among the emission of light (luminescence) from thermally excited substances/ molecules under suitable excitation devoid of escalating their average kinetic energy.

After 1900, the modern period luminescence experimentations were started on the inspirations of promising quantum mechanics approaches [4-6]. During the antediluvian 1900s, the progress of quantum theory bestowed a concrete evidence on theoretical groundwork about the enormous accretion of spectroscophical facts. A comprehensive understanding of luminescent emission led from quantum theory, which voluntarily elucidating prior inter- 
pretation and consenting predictions of innovative occurrence. Subsequently, during the period of 1920-1930, theoretical concepts of luminescence are very well implicit among researchers, and it was documented to facilitate luminescence spectroscopy is intrinsically added novel perceptive than absorption spectroscopy. A minimum of five independent luminescence properties are able to be estimated which are the features of a testing sample module [4-6]:

1. Emission intensity by monitoring the excitation wavelength.

2. Excitation intensity by monitoring the emission wavelength.

3. Decay time of the excited state.

4. Emission of polarization.

5. Quantum yield.

6. Anisotropy.

As an assessment, the merely alternative variable calculated using absorption spectroscopy is the transmission spectra (Beer-Lambert law). However, most studies concern the activity of luminescence concepts in the prediction of innovative occurrences as summarized in Table 1.

\begin{tabular}{|c|c|c|}
\hline Type & Examples & Applications \\
\hline Fluorescence & $\begin{array}{l}\text { Lignum nephriticum ('kidneywood'), aragonite, } \\
\text { and so on (in all the below cited luminescence } \\
\text { types) [7] }\end{array}$ & $\begin{array}{l}\text { Display devices, fluorescent } \\
\text { hydrogels, biomarkers }\end{array}$ \\
\hline Phosphorescence & $\begin{array}{l}\mathrm{Eu}^{2+} \text {-doped strontium silicate-aluminate and so on } \\
\text { (in all the below cited luminescence types) [8] }\end{array}$ & $\begin{array}{l}\text { Traffic signals, phosphorescent paint } \\
\text { ('Leuchtgelb’) }\end{array}$ \\
\hline Photoluminescence & $\begin{array}{l}\text { Halophosphate (fluoro-or chloro-apatite): } \\
\mathrm{Ca}_{5}\left(\mathrm{PO}_{4}\right)_{3}(\mathrm{~F}, \mathrm{CI}): \mathrm{Sb}^{3+}, \mathrm{Mn}^{2+}[9]\end{array}$ & Fluorescent lamp \\
\hline Radioluminescence & $\begin{array}{l}\text { Paint with radium, gaseous tritium light source } \\
\text { (GTLS) [10] }\end{array}$ & $\begin{array}{l}\text { Wristwatch faces, gun sights, nuclear } \\
\text { reactors and radioisotopes }\end{array}$ \\
\hline Cathodoluminescence & $\mathrm{Ca}_{3} \mathrm{Gd}_{7}\left(\mathrm{PO}_{4}\right)\left(\mathrm{SiO}_{4}\right)_{5} \mathrm{O}_{2}: \mathrm{Ce}^{3+}, \mathrm{Tb}^{3+}$ and $\mathrm{Mn}^{2+}[11]$ & $\begin{array}{l}\text { Cathode ray tube, monitors, field } \\
\text { emission device }\end{array}$ \\
\hline Electroluminescence & $\mathrm{Zn}(\mathrm{S}, \mathrm{Se}): \mathrm{Cu}^{+}, \mathrm{ZnS}: \mathrm{Cu}^{+}[12]$ & LED, EL displays \\
\hline Thermoluminescence & $\mathrm{ZnS}: \mathrm{Mn}^{2+}$, Radioactive irradiation, quartz $[13,14]$ & $\begin{array}{l}\text { Archaeology, dating of burnt flint, } \\
\text { pressure gauge temperature }\end{array}$ \\
\hline Chemiluminescence & $\begin{array}{l}\text { Oxidation of luminol, fluorescein, rhodamines, } \\
\text { coumarins, oxazines [15] }\end{array}$ & Analytical chemistry \\
\hline Bioluminescence & Green fluorescent protein [16] & Cell tracking, fast-acting biocides \\
\hline $\begin{array}{l}\text { Candoluminescence/ } \\
\text { Pyroluminescence }\end{array}$ & $\begin{array}{l}\text { Zinc oxide and cerium oxide or thorium dioxide, } \\
\text { trimethyl borate, alkali metals and alkali earth } \\
\text { metals }[17,18]\end{array}$ & Gas mantles or limelight \\
\hline Galvanoluminescence & Electrolysis of sodium bromide (NaBr) [19] & Fabrication of electrolytic cell \\
\hline Sonoluminescence & Collapse of gas-filled bubbles in a liquid [20] & $\begin{array}{l}\text { Bomb-resistant baggage container for } \\
\text { wide body aircraft }\end{array}$ \\
\hline
\end{tabular}




\begin{tabular}{|c|c|c|}
\hline Type & Examples & Applications \\
\hline $\begin{array}{l}\text { Mechanoluminescence/ } \\
\text { Mechanochromic } \\
\text { luminescence }\end{array}$ & CaZnOS: $\mathrm{Mn}^{2+}$ and $\mathrm{CaZr}\left(\mathrm{PO}_{4}\right)_{2}: \mathrm{Eu}^{2+}[21]$ & $\begin{array}{l}\text { Mechanical stress in industrial } \\
\text { plants, structures and living bodies }\end{array}$ \\
\hline $\begin{array}{l}\text { Triboluminescence/ } \\
\text { Fractoluminescence }\end{array}$ & $\mathrm{ZnS}: \mathrm{Mn}^{2+}[22,23]$ & $\begin{array}{l}\text { Diamond, quartz, emission of } \\
\text { electromagnetic radiation (EMR)- } \\
\text { sensors/smart materials }\end{array}$ \\
\hline Crystaloluminescence & $\mathrm{NaCl}[24]$ & $\begin{array}{l}\text { Image intensification techniques } \\
\text { (spatial, temporal and spectral) }\end{array}$ \\
\hline Injection luminescence & LED [25] & Basic research \\
\hline Negative luminescence & InSb, $(\mathrm{Hg}, \mathrm{Cd}) \mathrm{Te}, \mathrm{Ge}$ and InAs [26] & Electronic device \\
\hline
\end{tabular}

Table 1. Different types of luminescence, with material examples, and field of applications.

Luminescence is a process having a wide range of applications in everyday life, starting from the conventional fluorescent lighting they extend to digital radiography in the field of magnetic resonance imaging (MRI) [27], electronic portal imaging device (EPID) [28], light-emitting diodes (LEDs) [29, 30], solid-state lasers [31], luminescent solar concentrators [32] and many/ much other electrical and electronic equipment employ luminescent materials. Recently, electroluminescent display that shows promise for making flexible electroluminescent flat panel display (FEL-FPD) technology [33] is emerging worldwide; it also provides an excellent platform for a foundation for a no-compromise hang-on-the wall TV. In the field of biochemistry and biophysics, the fluorescence spectroscopy and time-resolved fluorescence are deemed as the first and foremost research equipment and this prominence has transformed and expanded nowadays with modern spectroscophical equipment. Currently, fluorescence as one of the foremost tactics was meticulously utilized in dissimilar areas of biochemistry, cell and molecular biology, genetics, bioinformatics, microbiology, biometrics, forensics, flow cytometry, medical diagnostics, nanomaterials, DNA sequencing, etc. The usage of fluorescence proves a dramatic growth in cellular and molecular imaging. Fluorescence imaging should be able to disclose the localized analysis of intra-cellular molecules, every so often at the stage of the detection of single molecule [34].

\section{Technological advancements in the science of luminescence spectroscopy}

All and sundry is having numerous astonishing moments to have a high regard for the spectacular engagement in recreation of luminosity, the consequence and the good organization of the assistance offered through optical devices to expand our prospect, in addition to reward for its ensnared defects to make ourselves with optical illusions. The well-equipped spectroscophical techniques possess broad accessibility by means of ease procedure, selectivity, sensitivity, accuracy, speed and precision $[6,9,34]$. The novel applications of fluorescence have proffered innovative technological advancements over few decades and these technological features were rapidly implemented for ground-breaking research. It is pointed out that 
two-photon or multi-photon excitation and multi-photon microscopy is one of the important technologies by employing the fluorescence mechanism [35-38]. By two-photon absorption process fluorophores can be excited by means of femtosecond pump-pulse lasers with regular pulse width. These lasers have turned out to be simple to utilize and are equipped with microscopes in the recent days. Table 2 summarizes some major innovative technological advancement associated with the science of luminescence activities in a broad spectrum.

\begin{tabular}{ll}
\hline Instrumentation & References \\
\hline Time-resolved fluorescence spectroscopy & {$[6]$} \\
Transient-absorption spectroscopy (flash spectroscopy) & {$[39]$} \\
Time-resolved infrared spectroscopy & {$[40]$} \\
Time-resolved two-photon photoelectron (2PPE) spectroscopy (or) & {$[41-44]$} \\
time-resolved photoemission spectroscopy (or) & {$[45]$} \\
laser-based angle-resolved photoemission spectroscopy & {$[46,47]$} \\
Fluorescence lifetime imaging spectroscopy & {$[48]$} \\
Fluorescence correlation spectroscopy & {$[49]$} \\
Single-molecule fluorescence spectroscopy & {$[50]$} \\
Fluorescence microscopy (epi-fluorescence, confocal) & {$[51]$} \\
Two-photon excitation fluorescence microscopy & \\
Near-field scanning optical microscopy (or) optical stethoscopy & \\
\hline
\end{tabular}

Table 2. Different types of luminescence spectroscophical instrumentation.

In fluorescence microscopy, the controlled excitation from the phenomenon of two-photon excitation has created a prevalent employability. Only through the focal plane of a microscope the image processing could be achieved through multi-photon excitation process [49]. This is a major benefit, since fluorescence images may get deformed from fluorescence process from top and bottom of the focal plane. There is no definite phase fluorescence so as to reduce the dissimilarity in non-confocal fluorescence microscopy; as a result, the images are obtained with good resolution. Such images are currently being achieved in numerous research laboratories.

Recently, a variety of scientific themes in association to the perspective of analytical advancements in luminescence spectroscopy and luminescence-based imaging in the field of earth sciences and related disciplines were discussed in detail [52]. Cathodoluminescence (CL) spectroscopy can be employed to detect and differentiate diverse generation of minerals or mineral by its variable CL colours or as an efficient technique on behalf of spatially resolved analysis of point/lattice defects (e.g. radiation-induced defects or vacancies, or broken bonds induced from electron defects) in solids by using the CL spectral measurements [53]. A new approach where fluorescence methods combined with modern chemo-metric approaches, such as bio-specific and other sensors, shows significant potential in the detection of cultural heritage and its degradation, explosives, residues and their components using time-resolved photoluminescence spectroscopy (TRPL) and fluorescence lifetime imaging (FLIM) [54]. Similarly, the total reflection $x$-ray fluorescence (TXRF) spectrometry is an energy-dispersive 
x-ray method that is employed for determining the elemental and chemical analysis (in stainless steel metal release) and is also suitable for small-sample analyses like airborne silver nanoparticles (NPs) from fabrics [55].

Thus, the invention of modern luminescence technology-oriented spectroscophical tools employed with multi-photon excitation/emission is one of the most important mechanisms that encompasses with radiative energy transfer, energy transfer by resonant exchange, energy transfer by spatial process, energy exchange by spin coupling, energy transfer by non-resonant processes and so on, which involved during photophysical processes even in a molecular level. As a result, the up-to-date activity in luminescence-based spectroscophical instrumentation has been correlated to expand our prospects towards new ideas in the field of biological science, physical chemistry, food science, pharmacology, nanotechnology, photovoltaics/solar cells, LEDs and displays, environmental science and so on.

In connection to the aforementioned aspects, the proper evaluation of environmental risks pertinent to recent experimental standards with reference to technological perspectives based on the growth inhibition caused by the chemical substances require necessary qualitative assessment such as the assessment of mechanism articulating toxicity. Therefore, it is affirmed that this assessment is need to be developed for building improvement towards ecological preservation and to deep evasion against human health.

\section{Conclusion}

As discussed above, luminescence is not only well conceived, but a pioneer across the globe with innovative scientific developments; however, facts also demonstrate that it has been and will prolong to be imperative towards ground-breaking research against novel applications for the societal cause. The most important worldwide challenges amongst the major noteworthy progress are in diverse fields of biochemistry, cell, molecular biology, genetics, bioinformatics, microbiology, bioinformatics, biometrics, forensics, flow cytometry, medical diagnostics and the addition of nanotechnology. The dispute of novel spectroscophical/ microscopical innovation comprises interdisciplinary areas that must continue to be improved for these innovative global developments in spectral imaging, fluorescence lifetime, timecorrelated single-photon counting, kinetic chemical reaction rates, singlet-triplet dynamics, visual implants, non-invasive optical biopsy and neurology. Thus, studies on inimitable luminescence technological surroundings might provide an insights about atoms/molecules that may perhaps turn out to be the future harbingers of green energy in the upcoming scenario.

\section{Acknowledgements}

This work was partially supported by the Department of Science and Technology, Government of India (SR/FTP/PS-135/2011).

The authors apologize for inadvertent omission of any pertinent references. 


\section{Conflict of interest}

The authors declare that there is no conflict of interests regarding the publication of this paper.

\section{Author details}

Jagannathan Thirumalai

Address all correspondence to: thirumalaijg@gmail.com; jthirumalai@bsauniv.ac.in

Department of Physics, B. S. Abdur Rahman University, Vandalur, Chennai, Tamil Nadu, India

\section{References}

[1] Yen W. M., Weber M. J. Inorganic Phosphors: Compositions, Preparation and Optical Properties. 1st ed. Boca Raton, FL, USA: CRC Press; 2004. 456 p. DOI: 10.1201/9780203506325.

[2] Yen W. M., Shionoya S., Yamamoto H. Phosphor Handbook. 2nd ed. Boca Raton, FL, USA: CRC Press; 2007. 1057 p. DOI: 0-8493-3564-7.

[3] Harvey E. N. A History of Luminescence from the Earliest Times until 1900. 1st ed. Philadelphia, PA: American Philosophical Society; 1957. 774 p. DOI: 00390708.

[4] Goldberg M. C., Weiner E. R. The science of luminescence. In: Goldberg M. C., editor. Luminescence Applications in Biological, Chemical, Environmental, and Hydrological Sciences. 193rd Meeting. Denver, Colorado: ACS Symposium Series; Washington, DC: American Chemical Society; Vol. 383; December 30, 1989. p. 1-22. DOI: 10.1021/ bk-1989-0383.ch001.

[5] Widemann E. U. Fluorescenz und phosphorescenz I. Abhandlung(On Fluorescence and Phosphorescence). Ann. Phys. 1888;270(7):446-463. DOI: 10.1002/p.18882700703.

[6] Valeur B., Berberan-Santos M. N., editors. Molecular Fluorescence: Principles and Applications. 2nd ed. Germany: Wiley-VCH Verlag GmbH \& Co. KGaA; 2001. p. 1-399. DOI: $10.1002 / 9783527650002$.

[7] Acuna A. U., Amat-Guerri F. Early history of solution fluorescence: the lignum nephriticum of Nicolas Monardes. In: Wolfbeis O. S., (Series editor) Berberan-Santos M. N. (Vol. editors). Fluorescence of Supermolecules, Polymers, and Nanosystems. 4th ed. of Springer Series on Fluorescence. New York, NY, USA: Springer Science \& Business Media; 2007. p. 3-20. DOI: 10.1007/4242_2007_006.

[8] Sophya Preethi K. R., Lu C.-H., Thirumalai J., Jagannathan R., Natarajan T. S., Nayak N. U., Radhakrishna R., Jayachandran M., Trivedi D. C. $\mathrm{SrAl}_{4} \mathrm{O}_{7}: \mathrm{Eu}^{2+}$ nanocrystals: 
synthesis and fluorescence properties . J. Phys. D: Appl. Phys. 2004;37(19):2664-2669. DOI: $10.1088 / 0022-3727 / 37 / 19 / 009$.

[9] McCarthy G. J. The Rare Earths in Modern Science and Technology. 2nd ed. New York: Springer Science \& Business Media; 2012. 647 p. DOI: 10.1007/978-1-4613-3054-7.

[10] Bower K. E., Barbanel Y. A., Shreter Y. G., Bohnert G. W., editors. Polymers, Phosphors, and Voltaics for Radioisotope Microbatteries. 1st ed. Boca Raton, FL: CRC Press; 2002. 504 p. DOI: 10.1201/9781420041392.ch4.

[11] Zhang Y., Li G., Geng D., Shang M., Peng C., Lin J. Color-tunable emission and energy transfer in $\mathrm{Ca}_{3} \mathrm{Gd}_{7}\left(\mathrm{PO}_{4}\right)\left(\mathrm{SiO}_{4}\right)_{5} \mathrm{O}_{2}: \mathrm{Ce}^{3+} / \mathrm{Tb}^{3+} / \mathrm{Mn}^{2+}$ phosphors. Inorg. Chem. 2012;51(21): 11655-11664. DOI: 10.1021/ic3015578.

[12] Warkentin M., Bridges F., Carter S. A., Anderson M. Electroluminescence materials $\mathrm{ZnS}: \mathrm{Cu}, \mathrm{Cl}$ and $\mathrm{ZnS}: \mathrm{Cu}, \mathrm{Mn}, \mathrm{Cl}$ studied by EXAFS spectroscopy. Phys. Rev. B. 2007;75(7): 075301-075309. DOI: 10.1103/PhysRevB.75.075301.

[13] Zahedifar M., Taghavinia N., Aminpour M. Synthesis and Thermoluminescence of ZnS: $\mathrm{Mn}^{2+}$ Nanoparticles. In: Salamin Y. I., Hamdan N. M., Al-Awadhi H., Jisrawi N. M., Tabets N., editors. AIP Conference Proceedings; 10-12 April 2007; Sharjah (United Arab Emirates). Melville, NY: AIP Publishing; 2007. p. 128-132. DOI: 10.1063/1.2776701.

[14] McKeevers S. W. S., editor. Thermoluminescence of Solids. Volume 3 of Cambridge Solid State Science Series. Cambridge, England: Cambridge University Press; 1988. 392 p. DOI: 9780521368117.

[15] Abel B., Odukoya B., Mohammed M., Aslan K. Enhancement of the chemiluminescence response of enzymatic reactions by plasmonic surfaces for biosensing applications. Nano. Biomed. Eng. 2015;7(3):92-101. DOI: 10.5101/nbe.v7i3.p92-101.

[16] Tsien R. Y. The green fluorescent protein. Annu. Rev. Biochem. 1998;67(1):509-44. DOI: 10.1146/annurev.biochem.67.1.509.

[17] Minchin L. T. Luminescence of oxides under flame excitation. Trans. Faraday Soc. 1939;35(1):163-170. DOI: 10.1039/TF9393500163.

[18] Kitsinelis S., Kitsineliss S., editors. Light Sources. Basics of Lighting Technologies and Applications. $2^{\text {nd }}$ ed. Boca Raton, FL, USA: CRC Press; 2015. 295 p. DOI: 10.1201/ b18456-13.

[19] Sullivan R. R., Dufford R. T. A further study of galvano-luminescence. J. Opt. Soc. Am. 1931;21(8):513-523. DOI: 10.1364/JOSA.21.000513.

[20] McNamara W. B., III, Didenko Y. T., Suslick K. S. Sonoluminescence temperatures during multi-bubble cavitation. Nature. 1999;401(October):772-775. DOI: 10.1038/44536. 
[21] Zhang J.-C., Xu C.-N., Wang X. S., Long Y.-Z. Novel elastico-mechanoluminescence materials CaZnOS: $\mathrm{Mn}^{2+}$ and $\mathrm{CaZr}\left(\mathrm{PO}_{4}\right)_{2}: \mathrm{Eu}^{2+}$. J. Adv. Dielectrics. 2014;4(3):14300031430007. DOI: 10.1142/S2010135X14300035.

[22] Clegg W., Bourhill G., Sage I. Hexakis(antipyrine-O)terbium(III) triiodide at $160 \mathrm{~K}$ : confirmation of a centrosymmetric structure for a brilliantly triboluminescent complex. Acta Cryst. 2002;E58(4):m159-m161. DOI: 10.1107/S1600536802005093.

[23] Chmel A., Shcherbakov I. Fractoluminescence from brittle and ductile homogeneous solids. J. Lumin. 2014;153(September):85-89. DOI: 10.1016/j.jlumin. 2014.03.005.

[24] Alexander A. J. Deep ultraviolet and visible crystalloluminescence of sodium chloride. J. Chem. Phys. 2012;136(6):064512. DOI: 10.1063/1.3684548.

[25] Nakamura S., Chichibu S. F., editors. Introduction to Nitride Semiconductor Blue Lasers and Light Emitting Diodes. Illustrated ed. Boca Raton, FL, USA: CRC Press; 2000. 386 p. DOI: 10.1.1.398.4326.

[26] Malyutenko V. K. Negative luminescence in semiconductors: a retrospective view. Phys. E. 2004;20(3-4):553-557. DOI: 10.1016/j.physe.2003.09.008.

[27] Roux S., Bazzi R., Rivière C., Lux F., Perriatand P., Tillement O. Rare earth nanomaterials in magnetic resonance imaging. In: Yang T. T. T., editor. Rare Earth Nanotechnology. 1st ed. Boca Raton, FL, USA: CRC Press; 2012. 262 p. DOI: 978-981-4364-20-1.

[28] Yeboah C., Pistorius S. Monte Carlo studies of the exit photon spectra and dose to a metal/phosphor portal imaging screen. Med. Phys. 2000;27(2):330-339. DOI: 10.1118/1.598835.

[29] Ma M., Mont F. W., Yan X., Cho J., Fred S. E., Kim G. B., Sone C. S. Effects of the refractive index of the encapsulant on the light-extraction efficiency of light-emitting diodes . Opt. Exp. 2011;19(5):A1135-A1140. DOI: 10.1364/OE.19.0A1135.

[30] Krishnan R., Thirumalai J. Synthesis and up/down conversion luminescence properties of $\mathrm{Na}_{0.5} \mathrm{R}_{0.5} \mathrm{MoO}_{4}: \mathrm{Ln}^{3+}\left(\mathrm{R}^{3+}=\mathrm{La}, \mathrm{Gd}\right)\left(\mathrm{Ln}^{3+}=\mathrm{Eu}, \mathrm{Tb}, \mathrm{Dy}, \mathrm{Yb} / \mathrm{Er}\right)$ thin phosphor films grown by pulsed laser deposition technique. RSC Adv. 2014;4(109):64258-64266. DOI: 10.1039/ C4RA11274A.

[31] Barbet A., Paul A., Gallinelli T., Balembois F., Blanchot J.-P., Forget S., Chénais S., Druon F., Georges P. Light-emitting diode pumped luminescent concentrators: a new opportunity for low-cost solid-state lasers. Optica. 2016;3(5):465-468. DOI: 10.1364/OPTICA. 3.000465 .

[32] Meinardi F., McDaniel H., Carulli F., Colombo A., Velizhanin K. A., Makarov N. S., Simonutti R., Klimov V. I., Brovelli S. Highly efficient large-area colourless luminescent solar concentrators using heavy-metal-free colloidal quantum dots. Nat. Nanotechnol. 2015;10(10):878-885. DOI: 10.1038/nnano.2015.178. 
[33] Crawford G. P., editor. Flexible Flat Panel Displays. Wiley Series in Display Technology. Hoboken, NJ: John Wiley \& Sons; 2005. 556 p. DOI: 10.1002/0470870508.ch1.

[34] Lakowicz J. R., editor. Principles of Fluorescence Spectroscopy. 3rd ed. New York: Springer; 2006. XXVI, 954 p. DOI: 10.1007/978-0-387-46312-4.

[35] Justel T., Nikol H., Ronda C. New developments in the field of luminescent materials for lighting and displays. Angew. Chem. Int. Ed., . 1998;37(22):3084. DOI: 10.1002/ (SICI)1521-3773.

[36] Diaspro A., editor. Confocal and Two-Photon Microscopy, Foundations, Applications, and Advances. 1st ed. New York: Wiley-Liss; 2002. 580 p. DOI: 978-0471409205.

[37] Masters B. R., Thompson B. J., editors. Selected Papers on Multiphoton Excitation Microscopy. 1st ed. Washington, DC: SPIE Optical Engineering Press Bellingham; 2003. 694 p. DOI: 9780819447487.

[38] Zipfel W. R., Williams R. M., Webb W. W. Nonlinear magic: multiphoton microscopy in the biosciences. Nat. Biotechnol. 2003;21(11):1369-1377. DOI: 10.1038/nbt899 .

[39] Burda C., El-Sayed M. A. High-density femtosecond transient absorption spectroscopy of semiconductor nanoparticles. A tool to investigate surface quality. Pure Appl. Chem. 2000;72(1-2):165-177. DOI: 10.1351/pac200072010165.

[40] Muhammad S., Moncho S., Brothers E. N., Darensbourg M. Y., Darensbourg D. J., Bengali A. A. Time resolved infrared spectroscopy: kinetic studies of weakly binding ligands in an iron-iron hydrogenase model compound. Inorg. Chem. 2012;51(13):73627369. DOI: 10.1021/ic300785z.

[41] Stolow A., Bragg A. E., Neumark D. M. Femtosecond time-resolved photoelectron spectroscopy. Chem. Rev. 2004;104(4):1719-1758. DOI: 10.1021/cr020683w.

[42] Weinelt M. Time-resolved two-photon photoemission from metal surfaces. J. Phys.: Conde. Matt. 2002;14(43):R1099. DOI: 10.1088/0953-8984/14/43/202.

[43] Fauster T., Steinmann W. Two-photon photoemission spectroscopy of image states. In: Halevi, P., editor. Electromagnetic Waves: Recent Developments in Research. 2 ed. Photonic Probes of Surfaces, North Holland: Elsevier; 1995. p. 347-411. ISBN: 9780444821980 .

[44] Zhu X. Y. Electron transfer at molecule-metal interfaces: a two-photon photoemission study. Ann. Rev. of Phys. Chem. 2002;53(1):221-247. DOI: 10.1146/annurev.physchem. 53.082801.093725.

[45] Chang C.-W., Sud D., Mycek M.-A. Fluorescence lifetime imaging microscopy. In: Sluder G., Nordberg J. J., editors. Methods in Cell Biology. 3rd ed., Vol. 81. Amsterdam: Elsevier; 2007. p. 495-524. DOI: 10.1016/S0091-679X(06)81024-1

[46] Krichevsky O., Bonnet G. Fluorescence correlation spectroscopy: the technique and its applications. Rep. Prog. Phys. 2002;65(2):251-297. DOI: 10.1088/0034-4885/65/2/203. 
[47] Mayboroda O. A., van Remoortere A., Tanke H. J., Hokke C. H., Deelder A. M. A new approach for fluorescence correlation spectroscopy (FCS) based immunoassays. J. Biotechnol. 2003;107(2):185-192. DOI: 10.1016/j.jbiotec.2003.10.007.

[48] Roiter Y., Minko S. AFM single molecule experiments at the solid-liquid interface: in situ conformation of adsorbed flexible polyelectrolyte chains. J. Am. Chem. Soc. 2005;127(45):15688-15689 . DOI: 10.1021/ja0558239.

[49] Huang B., Bates M., Zhuang X. Super resolution fluorescence microscopy. Annu Rev Biochem. 2009;78(1):993-1016. DOI: 10.1146/annurev.biochem.77.061906.092014.

[50] Svoboda K., Yasuda R. Principles of two-photon excitation microscopy and its applications to neuroscience. Neuron. 2006;50(6):823-839. DOI: 10.1016/j.neuron. 2006.05.019.

[51] Dürig U., Pohl D. W., Rohner F. Near-field optical scanning microscopy. J. Appl. Phys. 1986;59(10):3318. DOI: 10.1063/1.336848.

[52] Nasdala L., Götze J., Hanchar M. Luminescence spectroscopy and imaging: analytical advances and perspectives in the Earth sciences and related disciplines. Miner Petrol. 2013;107:349-351. DOI: 10.1007/s00710-013-0292-4.

[53] Götze J. Potential of cathodoluminescence (CL) microscopy and spectroscopy for the analysis of minerals and materials. Anal. Bioanal. Chem. 2002;374:703-708. DOI 10.1007/s00216-002-1461-1.

[54] Nevin A., Cesaratto A., Belle S., D’andrea C., Toniolo L., Valentini G., Comelli D. Timeresolved photoluminescence spectroscopy and imaging: new approaches to the analysis of cultural heritage and its degradation. Sensors. 2014;14:6338-6355. DOI: 10.3390/s140406338.

[55] Dalipi R., Borgese L., Casaroli A., Boniard M., Fittschen U., Tsuji K., Depero L. E. Study of metal release from stainless steels in simulated food contact by means of total reflection X-ray fluorescence. J. Food Engineering. 2016;173:85-91. DOI: 10.1016/ j.jfoodeng.2015.10.045. 